\title{
Journal of Parasitology
}

\section{Broader geographic sampling increases extent of intermediate host specificity for a trematode parasite (Notocotylidae: Quinqueserialis quinqueserialis) \\ --Manuscript Draft--}

\begin{tabular}{|c|c|}
\hline Manuscript Number: & 19-16R2 \\
\hline Full Title: & $\begin{array}{l}\text { Broader geographic sampling increases extent of intermediate host specificity for a } \\
\text { trematode parasite (Notocotylidae: Quinqueserialis quinqueserialis) }\end{array}$ \\
\hline Short Title: & Broader geographic sampling reveals novel hosts \\
\hline Article Type: & Short Communications \\
\hline Corresponding Author: & $\begin{array}{l}\text { Jillian T Detwiler } \\
\text { University of Manitoba } \\
\text { Winnipeg, MB CANADA }\end{array}$ \\
\hline \multicolumn{2}{|l|}{$\begin{array}{l}\text { Corresponding Author Secondary } \\
\text { Information: }\end{array}$} \\
\hline Corresponding Author's Institution: & University of Manitoba \\
\hline \multicolumn{2}{|l|}{$\begin{array}{l}\text { Corresponding Author's Secondary } \\
\text { Institution: }\end{array}$} \\
\hline First Author: & Demi K Gagnon \\
\hline \multicolumn{2}{|l|}{ First Author Secondary Information: } \\
\hline \multirow[t]{2}{*}{ Order of Authors: } & Demi K Gagnon \\
\hline & Jillian T Detwiler \\
\hline \multicolumn{2}{|c|}{ Order of Authors Secondary Information: } \\
\hline Abstract: & $\begin{array}{l}\text { Knowledge of helminth life cycles is essential to understanding their host specificity, } \\
\text { geographic distribution, and transmission. Many helminth life cycle descriptions are } \\
\text { based on field collections in a limited part of the parasite's range. However, it is } \\
\text { important to determine whether helminth life cycles and host specificity remain } \\
\text { consistent across their geographic range so that we may better understand their life } \\
\text { history and transmission ecology. Here, we investigated whether the life cycle of a } \\
\text { widespread trematode, Quinqueserialis quinqueserialis (Notocotylidae) varies across } \\
\text { its geographic range. Four species of planorbid snails; Gyraulus circumstriatus, G. } \\
\text { crista, Planorbula sp., and Promenetus exacuous were collected at } 5 \text { locations in } \\
\text { Canada ( } 3 \text { in Manitoba, } 2 \text { in Northwest Territories). Snails and parasite larvae were } \\
\text { morphologically and genetically identified to species. Total prevalence of Q. } \\
\text { quinqueserialis infections in snail hosts among the } 5 \text { locations was } 2.3 \% \text { ( } \mathrm{n}=1017 \text { ). } \\
\text { Three species of snails were infected with Q. quinqueserialis rediae: G. circumstriatus, } \\
\text { G. crista, and P. exacuous. Two of the } 3 \text { species of snails were infected in central } \\
\text { (Manitoba) and northern locations (Northwest Territories) within Canada, which } \\
\text { indicates limited life cycle variation across a large geographic range. This is the first } \\
\text { report of snails naturally infected with Q. quinqueserialis in Canada. These novel host } \\
\text { records demonstrate that this trematode species is not as host specific for first } \\
\text { intermediate host species as previously described. }\end{array}$ \\
\hline
\end{tabular}


RH: SHORT COMMUNICATION

\title{
BROADER GEOGRAPHIC SAMPLING INCREASES EXTENT OF INTERMEDIATE HOST SPECIFICITY FOR A TREMATODE PARASITE (NOTOCOTYLIDAE: QUINQUESERIALIS QUINQUESRIALIS)
}

\author{
D. K. Gagnon and J. T. Detwiler \\ Department of Biological Sciences, University of Manitoba, Winnipeg, Canada, R3T 2N2. \\ Correspondence should be sent to J. T. Detwiler at: Jillian.Detwiler@umanitoba.ca
}

\section{ABSTRACT}

Knowledge of helminth life cycles is essential to understanding their host specificity, geographic distribution, and transmission. Many helminth life cycle descriptions are based on field collections in a limited part of the parasite's range. However, it is important to determine whether helminth life cycles and host specificity remain consistent across their geographic range so that we may better understand their life history and transmission ecology. Here, we investigated whether the life cycle of a widespread trematode, Quinqueserialis quinqueserialis (Notocotylidae) varies across its geographic range. Four species of planorbid snails; Gyraulus circumstriatus, Gyraulus crista, Planorbula sp., and Promenetus exacuous were collected at 5 locations in Canada (3 in Manitoba, 2 in Northwest Territories). Snails and parasite larvae were morphologically and genetically identified to species. The total prevalence of $Q$. quinqueserialis infections in snail hosts among the 5 locations was $2.3 \%(\mathrm{n}=1,017)$. Three species of snails were infected with $Q$. quinqueserialis rediae: G. circumstriatus, G. crista, and P. exacuous. Two of the 3 species of snails were infected in central (Manitoba) and northern locations (Northwest Territories) within Canada, which indicates limited life cycle variation across a large geographic range. This is the first report of snails naturally infected with $Q$. quinqueserialis in Canada. These novel host 
records demonstrate that this trematode species is not as host-specific for first intermediate host species as previously described.

\section{KEY WORDS}

Canada, Field Survey, Gyraulus, Life Cycle Variation, New Host Records, Promenetus

Understanding the life cycles of helminth parasites is essential to establishing their host specificity, geographic range, and transmission. However, most helminth life cycles have not been elucidated or if they have, they have been revised as more life history studies of the parasite have been completed (Bolek et al., 2016). One reason for these revisions is that many life cycle descriptions are based on field collections in 1 part of the entire range of the parasite. However, some parasites have large geographic ranges that can span entire continents. For such parasites, it is important to determine whether their life cycle and host specificity are similar across that range.

One example of a parasite with an established life cycle and a large geographic range is Quinqueserialis quinqueserialis (Trematoda: Notocotylidae). Initially, Q. quinqueserialis was described from adults collected from muskrats (Ondatra zibethicus) and meadow voles (Microtus pennsylvanicus) in Nebraska and Alaska (Barker and Laughlin, 1911; Rausch, 1952). This trematode species has been reported in muskrats across the United States and Canada, with the northern limit of its range above the arctic circle and the southern limit of its range reaching the southeastern United States (i.e., Rausch, 1952; Detwiler et al., 2012). Decades after the original description, the life cycle was completed in North America after larvae were found in the freshwater snail Gyraulus parvus collected in Michigan (Herber, 1942). Then, over 40 yr later in Russia, another snail species, Gyraulus stroemi was identified as the intermediate host of $Q$. quinqueserialis through field surveys and experimental infections using field-infected snails and laboratory mice (Zhaltsanova and Beliakova, 1986). However, a second 
Quinqueserialis species, Quinqueserialis wolgaensis, that infects water voles (Arvicola terrestris) also occurs throughout Russia (Skvortsov, 1935). Without genetic identification of rediae from infected $G$. stroemi in Russia, it is unclear whether this snail species acts as an intermediate host to either $Q$. quinqueserialis or Q. wolgaensis. The report of a potential novel host in a different part of the parasite's range suggests that as first intermediate host specificity is examined across a wide geographic range, additional hosts may be found. Yet, most subsequent reports of $Q$. quinqueserialis have been of the adult stage identified from the definitive hosts (e.g., McKenzie and Welch, 1979; Rigby and Threlfall, 1981; Haukisalmi et al., 1995; Zabiega, 1996; Seegers et al., 1997; Detwiler et al., 2012). Thus, knowledge of the intermediate host range is limited. For example, there are no reports of Q. quinqueserialis in naturally-infected snails in Canada (Gordy et al., 2016).

To complete the life cycle of $Q$. quinqueserialis and test the hypothesis that life cycle variation will occur in different parts of the parasite's geographic range, we surveyed 4 species of pulmonate snails in the family Planorbidae. Snails were collected at 5 locations (3 in Manitoba and 2 in Northwest Territories, Canada) in June-August 2018 and examined for the presence of Q. quinqueserialis. The locations included a pond adjoining a river (Marais River, MB: $49^{\circ} 07.75^{\prime} \mathrm{N}, 097^{\circ} 16.98^{\prime} \mathrm{W}$ ); a road-side ditch abutting a wetland (Libau, MB: 50 $\left.18.81^{\prime} \mathrm{N}, 096^{\circ} 42.49^{\prime} \mathrm{W}\right)$; a marsh (Oak Hammock Marsh, MB: $50^{\circ} 11.287^{\prime} \mathrm{N}, 097^{\circ} 07.004^{\prime} \mathrm{W}$ ); a creek (Onion Lake Creek, NWT: $68^{\circ} 17.95^{\prime} \mathrm{N}, 133^{\circ} 35.81^{\prime} \mathrm{W}$ ): and a channel (Leland Channel, NWT: $68^{\circ} 37.39^{\prime} \mathrm{N}, 135^{\circ} 22.15^{\prime} \mathrm{W}$ ).

At each of the 5 locations, snails were haphazardly collected by hand over a $2 \mathrm{hr}$ period, placed in buckets containing water from the collection location, and transported back to the laboratory. Snails were placed in 6-well cell culture plates, filled with non-treated water, and exposed to light for a minimum of $3 \mathrm{hr}$ to promote the emergence of cercariae (Detwiler and Minchella, 2009). If cercariae emerged from the snail, the morphotypes were identified using the larval trematode key by Schell 
(1985). Live cercariae with a monostome morphotype were imaged with an Axio Imager M2 compound microscope (Zeiss Canada Ltd., Toronto, Canada). Due to equipment limitations at the field station in Northwest Territories, no images of live cercariae were obtained from this location. Snails from all 5 locations infected with the monostome morphotype were crushed, and rediae and cercariae were preserved in $80 \%$ ethanol. Snails that did not shed cercariae were also crushed and examined for latent infections. Snail species were initially identified using shell morphology characteristics following descriptions by Clarke (1981). Snail foot tissue was preserved in $80 \%$ ethanol.

Rediae collected from the same snail host as imaged cercariae were used in DNA extractions. Tissue samples were soaked in MilliQ water to remove the ethanol prior to being incubated in $200 \mu 1$ $5 \%$ Chelex solution with $0.2 \mathrm{mg} / \mathrm{ml}$ proteinase $\mathrm{K}$ at $56 \mathrm{C}$ for $2 \mathrm{hr}$. DNA samples were then vortexed, boiled at $100 \mathrm{C}$ for $8 \mathrm{~min}$ and vortexed again after cooling. Extracted DNA samples were stored at $-20 \mathrm{C}$ until polymerase chain reaction (PCR) could be performed. A 1,000 base pair (bp) fragment of the $28 S$ ribosomal RNA gene region was amplified using the forward primer 300F (5' CAA GTA CCG TGA GGG AAA GTT G 3') and the reverse primer 1500-R (5' GCT AGG GAA ACT TCG 3') (Olson et al., 2003). The $28 S$ gene region was targeted to compare our sequences to an isolate of $Q$. quinqueserialis deposited in GenBank (JQ670848.1; Detwiler et al., 2012). Amplification was carried out in a $25 \mu 1$ reaction solution containing $2 \mu 1$ of extracted DNA, $2.5 \mathrm{mM} 10 \mathrm{x}$ buffer, $1.5 \mathrm{mM} \mathrm{MgCl}_{2}, 0.5 \mathrm{mM}$ of dNTPs and each primer, and 0.05 unit/ $\mu$ of Taq polymerase. The amplification had an initial denaturation at $95 \mathrm{C}$ for $3 \mathrm{~min}$ followed by 40 cycles of denaturation ( $94 \mathrm{C}, 45 \mathrm{sec}$ ), annealing (56 C, 30 sec), and extension (72 C, $2 \mathrm{~min}$ ), with a final extension phase at $72 \mathrm{C}$ for $7 \mathrm{~min}$.

To confirm the morphological species identification of field-collected snails, we performed DNA barcoding with primers for the cytochrome c oxidase subunit I gene $(\mathrm{CO})$. DNA was extracted from snails using the E.Z.N.A. Mollusc DNA Kit according to the manufacturer's instructions (Omega Bio- 
Tek, cat. No. D3373-02). The Folmer region ( 650 bp) of CO1 was targeted using primers LCO1490 (5'GGTCAACAAATCARAAAGATATTGG 3') and HCO2198

(5'TAAACTTCAGGGTGACCAAAAAATCA 3') (Folmer et al., 1994). Amplification was carried out in $25 \mu \mathrm{l}$ reaction volumes with $50 \mathrm{ng}$ of DNA, $1 \mathrm{x}$ buffer, $1.5 \mathrm{mM} \mathrm{MgCl} 2,0.2 \mathrm{mM}$ of each dNTP, 0.4 $\mathrm{mM}$ of each primer, and 0.05 unit/ $\mu \mathrm{l}$ Taq polymerase. The amplification was completed with a thermocycler profile following that of Gordy et al. (2016).

Polymerase chain reaction (PCR) products were visualized with $2 \%$ agarose gels and products with single bright bands were purified with a PCR clean up kit (MO BIO Laboratories Inc., Carlsbad, California). Purified products were sequenced in both directions at the Hospital for Sick Children, Toronto, Ontario, Canada using an ABI 3730XL Sanger Sequencer (ThermoFisher, Waltham, Massachusetts). Contigs were constructed and manually edited by eye in Sequencher v. 4.1 (Gene Codes Corporation, Ann Arbor, Michigan) and alignments were generated using ClustalW in MEGA 7.0 (Kumar et al., 2016). Genetic distances between all individuals were calculated with p-distance in MEGA.

The total prevalence of monostome infections in planorbid snails collected at the 5 locations was $2.3 \%(\mathrm{n}=1,017)$ with a mean prevalence $( \pm \mathrm{SE})$ of $3 \%( \pm 1.4)$ per location (Table I). A total of 14 sequences were obtained from individual rediae that were each recovered from an infected snail: 3 from Northwest Territories and 11 from Manitoba. All of these $28 S$ sequences were identical to each other, but were $0.4 \%$ different across 907 bp compared to a sequence from an adult Q. quinqueserialis collected from a muskrat in Virginia (JQ670848). One sequence representing the larval $Q$. quinqueserialis collected in Northwest Territories and Manitoba was deposited in GenBank (MK251989). 
Among the 5 locations, 4 species of planorbid snails were collected, however, monostome infections only occurred in 3 species: Gyraulus circumstriatus, Gyraulus crista, and Promenetus exacuous (Table I). Using shell morphology, we identified the snails as G. sp., G. crista, and $P$. exacuous. Initially, we did not identify Gyraulus to species because of the phenotypic plasticity observed in key shell characteristics such as shell opacity and striae (Clarke, 1981). Further, G. parvus and G. circumstriatus can be confused based on morphological identification alone (Clarke, 1981). BLAST searches of genetic sequences from morphologically identified samples of G. crista and $P$. exacuous had high percent identity to other GenBank samples identified as the same species, respectively. A genetic sequence from G. crista collected from Oak Hammock Marsh, MB was 97\% identical over 655 bp to G. crista (KC495836). Two genetic sequences from P. exacuous from Libau, MB and Leland Channel, NWT were 100\% identical over 604 bp to P. exacuous (MG421197, MG421621, MG421977, MG422064, MG422315, MG422776, MG423081, MG423194, MG423308, MG423392, MG423429, MG423538). Three genetic sequences from G. sp. collected from Marais River and Oak Hammock Marsh, MB; Onion Lake Creek, NWT were 99\% identical over 670 bp to $G$. circumstriatus (MF544182, MF544479, MF545123, MG421037, MG421138, MG421420, MG421423, MG421962, MG421983, MG422619, MG422627, MG422893, MG422911, MG423191, MG423252, MG423237, MG423312). One significant contribution of this study is to have deposited genetic vouchers for the snail hosts (MN109972, MN109973, MN109974, MN109975, MN109976, MN109977). Without these vouchers, it is difficult to determine whether the snails in the previous life cycle studies were correctly identified (i.e., Herber, 1942; Zhaltsanova and Beliakova, 1986). Future studies can use our genetic sequences of hosts to further evaluate life cycle variation in $Q$. quinqueserialis. 
Our study confirms that $Q$. quinqueserialis has a wide geographic range in Canada that spans from the Northwest Territories to Manitoba ( 2,989 km). On one hand, our results suggest that $Q$. quinqueserialis is not as specialized for gastropod hosts as previously described (Herber, 1942). By using at least 4 host species instead of a single snail host, it could be considered more of a generalist parasite (Poulin et al., 2011). On the other hand, 2 of the 3 host species were used by the parasite at the northern and central parts of its range suggesting consistency in host specificity across a broad geographic extent (Poulin et al., 2011). Further, all the host species were confamilial. Thus, despite using a relatively high number of compatible intermediate hosts, $Q$. quinqueserialis parasites may be considered more specialized in the sense that host specificity is similar across its distribution and host phylogeny.

Prevalence of $Q$. quinqueserialis was relatively low in each snail host (Table I). However, $Q$. quinqueserialis is successful in infecting definitive hosts typically with prevalence of infection over 80\%, with individuals hosting a mean of 100 worms (e.g., McKenzie and Welch, 1979; Rigby and Threlfall, 1981). The discrepancy between first intermediate host and definitive host prevalence demonstrates transmission success despite low infection numbers among snail hosts. Exploiting more than 1 intermediate host species could increase the likelihood of transmission to the definitive host. Quinqueserialis quinqueserialis parasites do not use a mobile second intermediate host, but instead, cercariae disperse and encyst on aquatic vegetation (Herber, 1942). Thus, exploiting several intermediate host species within the same habitat, in addition to the metacercarial stage persisting in the environment, could increase transmission success.

Life cycle and host range information are critical for understanding the transmission ecology of wildlife parasites. Here, we demonstrate the importance of host surveys across a broad geographic range in determining the host specificity and infection dynamics of trematode parasites. In contrast to our 
hypothesis, we found little evidence for life cycle variation across the geographic range of the trematode Q. quinqueserialis. Instead, we found that the parasite used nearly the same set of gastropod species as first intermediate hosts in geographically distant parts of its range. Importantly, all of these host species were not previously known to transmit this parasite making this the first report of snails naturallyinfected with Q. quinqueserialis in Canada (Herber, 1942; Gordy et al., 2016).

We thank Hank Angasuk, Ryan McLeod, and Scott Kasook for acting as guides to locations in the Northwest Territories. This project was funded by the University of Manitoba's Fieldwork Support Program and a NSERC Discovery grant to J. T. Detwiler; the Northern Scientific Training Program (NSTP) and the University of Manitoba's Oakes-Riewe Environmental Research Award to D. K. Gagnon.

\section{LITERATURE CITED}

Barker, F. D., and J. W. Laughlin. 1911. A new species of trematode from the muskrat, Fiber zibethicus. Transactions of the American Microscopical Society 30: 261-274.

Bolek, M. G., H. A. Stigge, and K. D. Gustafson. 2016. The iron wheel of parasite life cycles: Then and now! In A century of parasitology: Discoveries, ideas and lessons learned by scientists who published in the Journal of Parasitology, 1914-2014, J. Janovy Jr. and G. W. Esch (eds.). John Wiley \& Sons, Ltd., Chichester, U.K., p. 131-147.

Clarke, A. H. 1981. The freshwater molluscs of Canada. National Museum of Natural Sciences, Ottawa, Canada, 446 p.

Detwiler, J. T., and D. J. Minchella. 2009. Intermediate host availability masks the strength of experimentally-derived colonisation patterns in echinostome trematodes. International Journal for Parasitology 39: 585-590. 
Detwiler, J. T., A. M. Zajac, D. J. Minchella, and L. K. Belden. 2012. Revealing cryptic parasite diversity in a definitive host: Echinostomes in muskrats. Journal of Parasitology 98: 1148-1155. Folmer, O., M. Black, W. Hoeh, R. Lutz, and R. Vrijenhoek. 1994. DNA primers for amplification of mitochondrial cytochrome $c$ oxidase subunit I from diverse metazoan invertebrates. Molecular Marine Biology and Biotechnology 3: 294-299.

Gordy, M. A., L. Kish, M. Tarrabain, and P. C. Hannington. 2016. A comprehensive survey of larval digenean trematodes and their snail hosts in central Alberta, Canada. Parasitology Research 115: 38673880.

Haukisalmi, V., H. Henttonen, and G. O. Batzli. 1995. Helminth parasitism in the voles Microtus oeconomus and M. miurus on the North Slope of Alaska: Host specificity and the effects of host sex, age and breeding status. Annales zoologici Fennici 32: 193-201.

Herber, E. C. 1942. Life history studies on two trematodes of the subfamily Notocotylidae. Journal of Parasitology 28: 179-196.

Kumar, S., G. Stecher, and K. Tamura. 2016. MEGA7: Molecular evolutionary genetics analysis version 7.0 for bigger datasets. Molecular Biology and Evolution 33: 1870-1874.

McKenzie, C. E., and H. E. Welch. 1979. Parasite fauna of the muskrat, Ondatra zibethica (Linnaeus, 1766) in Manitoba, Canada. Canadian Journal of Zoology 57: 640-646.

Olson, P. D., T. H. Cribb, V. V. Tkach, R. A. Bray, and D. T. J. Littlewood. 2003. Phylogeny and classification of the Digenea (Platyhelminthes: Trematoda). International Journal for Parasitology 33: 733-755.

Poulin, R., B. R. Krasnov, and D. Mouillot. 2011. Host specificity in phylogenetic and geographic space. Trends in Parasitology 27: 355-361. 
Rausch, R. 1952. Studies on the helminth fauna of Alaska. XI. Helminth parasites of microtine rodents - taxonomic considerations. Journal of Parasitology 38: 415-444.

Rigby, M. D., and W. Threlfall. 1981. Helminth parasites of the muskrat (Ondatra zibethicus (L.)) in Newfoundland. Canadian Journal of Zoology 59: 2172-2176.

Seegers, G., S. Baumeister, S. Kuschfeldt, K. Pohlmeyer, and M. Stoye. 1997. Nematode and trematode fauna of the muskrat (Ondatra zibethicus LINK, 1795) in Lower Saxony. Deutsche Tierarztliche Wochenschrift 104: 503-504.

Schell, S. C. 1985. Handbook of trematodes of North America, North of Mexico. University Press of Idaho, Moscow, Idaho, 263 p.

Skvortsov, A. A. 1935. On a study of the helminth fauna of the water rat, Arvicola terrestris. Vestnik Microbiologii Epidemiologii i Parazitologii 13: 317-326.

Zabiega, M. H. 1996. Helminths of mink, Mustela vison, and muskrats, Ondatra zibethicus, in Southern Illinois. Journal of the Helminthological Society of Washington 63: 246-250.

Zhaltsanova, D. S., and I. V. Beliakova. 1986. Intermediate host of the trematode Quinqueserialis quinqueserialis (Trematoda, Notocotylidae) in the USSR and the morphology of its parthenitae and larvae. Parazitologiia 20: 323-326. 
Table I. Prevalence of Q. quinqueserialis infection in 4 snail species collected from 5 sampling locations across Canada. MB, Manitoba; NT, Northwest Territories.

\begin{tabular}{llc}
\hline Location & Snail species (N) & Prevalence (\%) \\
\hline Marais River, MB & Gyraulus circumstriatus (432) & 1.4 \\
& Promenetus exacuous (4) & 25 \\
Libau ditch, MB & Gyraulus circumstriatus (54) & 1.9 \\
& Gyraulus crista (1) & 0 \\
& Promenetus exacuous (43) & 2.3 \\
& Planorbula sp. (6) & 0 \\
Oak Hammock Marsh, MB & Gyraulus circumstriatus (69) & 7.3 \\
& Gyraulus crista (18) & 16 \\
& Promenetus exacuous $(6)$ & 0 \\
Onion Lake Creek, NT & Gyraulus circumstriatus (179) & 1.1 \\
& Promenetus exacuous (5) & 0 \\
Leland Channel, NT & Gyraulus circumstriatus (107) & 0 \\
& Promenetus exacuous (40) & 10 \\
& Planorbula sp. (53) & 0 \\
\hline
\end{tabular}


Click here to access/download Copyright Form Copyright_Manuscript19-16.pdf 
Click here to access/download Cover Letter 19-16R2 Response to Reviewers_submitted.docx 